\title{
UJI KESAHIHAN INTERNA DAN KEHANDALAN KUESIONER CABIN FEVER PHENOMENON (CFP) VERSI INDONESIA
}

\section{Yohanes Firmansyah ${ }^{1}$, Ernawati $\mathrm{Su}^{2}$, Ivan Buntara ${ }^{3}$, Hendsun $^{4}$, Fiolita Indranita Sutjipto ${ }^{5}$, Pinka Nurashri Setiyati ${ }^{6}$}

\author{
${ }^{1}$ Fakultas Kedokteran Universitas Tarumanagara, Jakarta Barat, Jakarta, Indonesia \\ Email: yohanesfirmansyah28@gmail.com \\ ${ }^{2}$ Fakultas Kedokteran Universitas Tarumanagara, Jakarta Barat, Jakarta, Indonesia \\ Email: dr.ernawati@gmail.com
}

${ }^{3}$ Fakultas Kedokteran Universitas Tarumanagara, Jakarta Barat, Jakarta, Indonesia

Email: buntara_ivan@yahoo.com

${ }^{4}$ Fakultas Kedokteran Universitas Tarumanagara, Jakarta Barat, Jakarta, Indonesia

Email: hendsunh@gmail.com

${ }^{5}$ Fakultas Kedokteran Universitas Tarumanagara, Jakarta Barat, Jakarta, Indonesia

Email: patriciafiolita@gmail.com

${ }^{6}$ Fakultas Kedokteran Universitas Trisakti, Jakarta Barat, Jakarta, Indonesia

Email:Pinkachairul@gmail.com

Masuk: 10-07-2020, revisi: 18-10-2020, diterima untuk diterbitkan: 25-10-2020

\begin{abstract}
ABSTRAK
Wabah dan isolasi akibat dirumah akibat dari wabah COVID-19 mungkin memiliki banyak konsekuensi pada kehidupan manusia dari segi psikologis. Konsekuensi psikologi yang tidak terdeteksi dini dapat menyebabkan permasalahan dikemudian hari yang dapat mengganggu kehidupan keluarga dan penderitanya, Oleh karena itu perlu adanya alat uji penapisan yang akurat serta handal dalam mendeteksi munculnya gejala psikiatri selama masa isolasi. Penelitian survei yang dilaksanakan di secara virtual melalui google form. Metode ini dipilih karena kondisi Pembatasan Sosial Skala Besar (PSBB) akibat Pandemik Covid-19 yang tidak memungkinkan untuk melakukan wawancara secara tatap muka. Sampel penelitian ini adalah seluruh masyarakat usia produktif dengan kriteria eksklusi berupa data yang tidak lengkap atau tidak bersedia mengikuti penelitian. Penelitian ini merupakan penelitian pendahuluan dari serangkaian proses uji kesahihan dan kehandalan. Analisa uji kesahihan internal menggunakan metode Pearson Product Moment dengan interpretasi bulir pertanyaan dikatakan sahih jika korelasi rho $(r) \geq 0,3$. Analisa uji kehandalan menggunakan metode pengujian Cronbach $\alpha$ dengan interpretasi handal bila nilai minimum Cronbach $\alpha$ sebesar 0,6. 281 responden yang memenuhi kriteria inklusi. Hasil pengujian dengan Pearson Product Moment atau Pearson Correlation didapatkan nilai rho (r) pada seluruh bulir pertanyaan adalah diatas 0,3 . Hasil uji kehandalan menggunakan uji Cronbach $\alpha$ adalah 0,935 dengan nilai Cronbach's Alpha if Item Deleted pada masing-masing bulir dibawah nilai Cronbach $\alpha_{.}$Cabin Fever Phenomenon (CFP) Versi Indonesia terbukti memiliki kesahihan yang baik serta kehandalan yang sangat baik untuk mendeteksi munculnya gejala psikiatri selama masa isolasi. Perlu dilakukan uji kesahihan lanjutan seperti uji kesahihan eksternal.
\end{abstract}

Kata Kunci: Cabin Fever Phenomenon; COVID-19; kesahihan dan kehandalan; psikiatri 


\section{ABSTRACT}

Outbreaks and isolation due to at home due to COVID-19 outbreaks may have many psychological consequences on human life. Psychological consequences that are not detected early can cause problems in the future that can disrupt the lives of families and sufferers, therefore the need for screening tests that are accurate and reliable in detecting the appearance of psychiatric symptoms during isolation.The survey research was carried out virtually via Google Form This method was chosen because of the condition of Large Scale Social Restrictions due to the Covid19 Pandemic, which made it impossible to conduct face-to-face interviews. The sample of this research is all of the productive age community with exclusion criteria in the form of incomplete data or unwilling to join the research. This research is a preliminary study of a series of validity and reliability test processes. Internal validity test analysis using the Pearson Product Moment method with the interpretation of the questions is said to be valid if the correlation rho $(r) \geq 0.3$. Analysis of reliability testing using the Cronbach $\alpha$ test method with reliable interpretation if the minimum value of Cronbach $\alpha$ is 0.6. 281 respondents who met the inclusion criteria. The results of testing with Pearson Product Moment or Pearson Correlation obtained the value of rho $(r)$ in all questions is above 0.3. The reliability test results using the Cronbach $\alpha$ test are 0.935 with the Cronbach's Alpha if Item Deleted value on each grain below the Cronbach $\alpha$ value. Cabin Fever Phenomenon (CFP) Indonesian Version is proven to have good validity and excellent reliability to detect the appearance of psychiatric symptoms during isolation. Further validity testing is needed such as an external validity test

Keywords: Cabin Fever Phenomenon; COVID-19; psychiatry; validity and reliability

\section{PENDAHULUAN}

\section{Latar Belakang}

Sejak Desember 2019, wabah baru dari virus strain betacoronavirus (COVID-19) telah menyebar dari Wuhan, Cina (Rothan \& Byrareddy, 2020; Schulmeyer, 2020; Sohrabi et al., 2020; Velavan \& Meyer, 2020), dan menjadi pandemi yang menyerang setiap benua (Sohrabi et al., 2020). Wabah COVID-19 telah mengakibatkan kematian hampir 383.000 orang di seluruh dunia pada hari-hari pertama Juni 2020 (Sohrabi et al., 2020).

Wabah dan isolasi akibat dirumah akibat dari wabah COVID-19 mungkin memiliki banyak konsekuensi pada kehidupan manusia dari segi psikologis yaitu dimulai dari munculnya stres kronis dan akut, kekhawatiran akan wabah, kematian tak terduga, hilangnya kontak social secara langsung, dan depresi akibat hilangnya pekerjaan. Isolasi akibat wabah COVID-19 juga membuat peningkatan akses akan media social. Seluruh perubahan psikologis ini tentu saja akan berdampak terhadap munculnya masalah kesehatan dikemudian hari dan masalah hubungan antar keluarga sebagai sesama manusia bila tidak ditangani dengan baik. (Guessoum et al., 2020)

Cabin fever mengacu pada iritabilitas claustrophobic atau kegelisahan yang dialami ketika seseorang, atau kelompok, terjebak di lokasi yang terisolasi atau di tempat terbatas untuk waktu yang lama. (Rosenblatt et al., 1984; Tonks, 2008)

Seseorang dapat mengalami Cabin fever dalam situasi seperti diisolasi dalam sebuah ruangan atau daerah yang cukup lama dengan akses komunikasi yang minimal seperti di penjara, panti, atau daerah terpencil. Seseorang yang mengalami Cabin fever mungkin mengalami kantuk atau sulit tidur, memiliki rasa tidak percaya pada siapa pun yang bersama mereka, atau memiliki keinginan untuk pergi ke luar bahkan dalam kondisi buruk seperti cuaca buruk atau jarak pandang terbatas. (Rosenblatt et al., 1984; Tonks, 2008)

Permasalahan muncul yaitu tidak adanya kuesioner baku untuk mendeteksi perubahan psikologis akibat terkurung dalam sebuah ruangan yang cukup lama atau alat uji penapisan dalam mendeteksi dini Cabin fever Phenomenon. Penelitian ini merupakan penelitian inovasi baru untuk membentuk kuesioner Cabin Fever Phenomenon yang dimulai dengan menguji validitas internal dan kehandalan dari kuesioner ini untuk digunakan di Indonesia. 


\section{METODE PENELITIAN}

Desain penelitian ini adalah penelitian survei yang dilaksanakan di secara virtual melalui google form. Metode ini dipilih karena kondisi Pembatasan Sosial Skala Besar (PSBB) akibat Pandemik Covid-19 yang tidak memungkinkan untuk melakukan wawancara secara tatap muka. Sampel penelitian ini adalah seluruh pekerja usia produktif baik yang menjalankan Work Form Home, Study Form Home (untuk mahasiswa), dan kelompok produktif yang mengalami pemutusan hubungan kerja (PHK). Kriteria inklusi penelitian ini adalah usia produktif yaitu usia 18 hingga 54 tahun. Kriteria eksklusi dalam penelitian ini adalah responden yang tidak bersedia menjadi responden, responden yang mengisi kuesioner secara tidak lengkap, dan responden yang tidak menjalankan protokol kesehatan sesuai ketentuan pemerintah. Metode pengambilan sampel pada penelitian adalah total sampling dengan jumlah sampel minimal yang diperlukan adalah 100 responden. Prosedur penelitian ini adalah dengan meminta responden untuk mengisi lembar persetujuan (inform Consent), lalu mengisi data dasar responden (usia, jenis kelamin, dan Pendidikan terakhir), data pekerjaan responden (jenis pekerjaan, WFH atau tidak, PHK atau tidak, dan pendapatan), serta protokol PSBB yang dilakukan. Setelah semua data terkumpul, responden diminta untuk mengisi pertanyaan kuesioner Cabin Fever Phenomenon yang telah dibuat oleh 1 ahli kesehatan masyarakat, 1 ahli ilmu social, dan 3 dokter dengan menghasilkan kuesioner Cabin Fever Phenomenon versi Indonesia yang terdiri dari 28 bulir pertanyaan (seluruh bulir pertanyaan ditampilkan pada bagian hasil penelitian).

Skala yang digunakan pada penelitian ini adalah skala ordinal yang berasal dari Likert, dengan data dianalisis kesahihan internal dan kehandalan sebagai Langkah awal untuk menentukan sebuah kuesioner layak atau tidak digunakan lebih lanjut sebelum pengujian uji sensitifitas, spesitifitas, dan uji validasi eksternal. Analisa uji kesahihan internal menggunakan metode Pearson Product Moment dengan interpretasi bulir pertanyaan dikatakan sahih jika korelasi rho (r) $\geq 0,3$. Analisa uji kehandalan menggunakan metode pengujian Cronbach $\alpha$ dengan interpretasi handal bila nilai minimum Cronbach $\alpha$ sebesar 0,6. Penelitian ini merupakan studi pendahuluan sebelum masuk kedalam tahap penelitian berikutnya.

\section{HASIL DAN PEMBAHASAN}

Proses pengumpulan data dilakukan pada bulan Mei 2020. Selama proses pengumpulan data dengan metode online atau google form didapatkan 281 responden yang memenuhi kriteria inklusi. Responden menjawab seluruh pertanyaan dengan nilai median adalah 0 poin, minimummaksimum adalah $0-3$ poin. Hasil pengujian dengan Pearson Product Moment atau Pearson Correlation didapatkan nilai rho (r) pada seluruh bulir pertanyaan adalah diatas 0,3 . Hasil uji kehandalan menggunakan uji Cronbach $\alpha$ adalah 0,935 dengan nilai Cronbach's Alpha if Item Deleted pada masing-masing bulir dibawah nilai Cronbach $\alpha$. Hasil uji kehandalan ini diinterpretasikan bahwa uji kehandalan kuesioner Kuesioner Cabin Fever Phenomenon (CFP) Versi Indonesia adalah sangat baik dikarenakan nilai Cronbach $\alpha$ berada dalam rentang 0,8 1,00 
Tabel 1. Hasil Validasi Internal dan Kehandalan Kuesioner Cabin Fever Phenomenon (CFP) Versi Indonesia

\begin{tabular}{|c|c|c|c|c|c|c|}
\hline No & Pertanyaan & $\begin{array}{c}\text { Mean } \\
(\mathbf{n}= \\
\mathbf{2 8 1})\end{array}$ & $\begin{array}{l}\text { Standar } \\
\text { Deviation } \\
\text { (SD) }\end{array}$ & $\begin{array}{l}\text { Corrected } \\
\text { Item Total } \\
\text { Correlation }\end{array}$ & $\begin{array}{c}\text { Cronbach's } \\
\text { Alpha if } \\
\text { Item } \\
\text { Deleted }\end{array}$ & $\begin{array}{c}\text { Cronbach's } \\
\text { Alpha } \\
\text { (Standarized } \\
\text { Items) }\end{array}$ \\
\hline 1 & Anda merasa lesu & 0.6441 & 0.71317 & 0.614 & 0.930 & \multirow{28}{*}{0.935} \\
\hline 2 & Anda merasa gelisah & 0.5587 & 0.67950 & 0.619 & 0.930 & \\
\hline 3 & Anda merasa mudah lelah & 0.6370 & 0.77684 & 0.572 & 0.931 & \\
\hline 4 & Anda merasa sedih & 0.6014 & 0.73523 & 0.702 & 0.929 & \\
\hline 5 & Anda merasa depresi & 0.3843 & 0.62818 & 0.613 & 0.930 & \\
\hline 6 & Anda merasa cemas & 0.6406 & 0.68842 & 0.563 & 0.931 & \\
\hline 7 & Anda merasa kesepian & 0.6441 & 0.82465 & 0.642 & 0.930 & \\
\hline 8 & Anda merasa bosan & 1.2633 & 0.89943 & 0.558 & 0.931 & \\
\hline 9 & Anda merasa sulit untuk konsentrasi & 0.6690 & 0.80227 & 0.675 & 0.929 & \\
\hline 10 & Anda menjadi kurang sabaran & 0.5943 & 0.76939 & 0.642 & 0.930 & \\
\hline 11 & Anda menjadi lebih mudah tersinggung & 0.4591 & 0.69122 & 0.583 & 0.930 & \\
\hline 12 & $\begin{array}{l}\text { Anda merasa tidak puas bila berada di } \\
\text { rumah }\end{array}$ & 0.6904 & 0.80637 & 0.636 & 0.930 & \\
\hline 13 & $\begin{array}{l}\text { Anda merasa tertekan / terjebak bila } \\
\text { berada di rumah }\end{array}$ & 0.4769 & 0.72727 & 0.619 & 0.930 & \\
\hline 14 & Anda sering mengidamkan makanan & 1.2135 & 0.88072 & 0.504 & 0.932 & \\
\hline 15 & $\begin{array}{l}\text { Anda merasa tidak memiliki motivasi / } \\
\text { motivasi berkurang }\end{array}$ & 0.6406 & 0.75285 & 0.587 & 0.930 & \\
\hline 16 & $\begin{array}{l}\text { Anda cenderung untuk menghindar dari } \\
\text { orang lain }\end{array}$ & 0.6192 & 0.80679 & 0.519 & 0.931 & \\
\hline 17 & $\begin{array}{l}\text { Anda cenderung tidak percaya dengan } \\
\text { orang lain }\end{array}$ & 0.5730 & 0.71403 & 0.542 & 0.931 & \\
\hline 18 & $\begin{array}{l}\text { Anda merasa sulit untuk bangun dari } \\
\text { tidur }\end{array}$ & 0.6548 & 0.83563 & 0.587 & 0.930 & \\
\hline 19 & Anda kesulitan untuk memulai tidur & 0.8754 & 0.93473 & 0.587 & 0.931 & \\
\hline 20 & $\begin{array}{l}\text { Anda sering menghabiskan waktu } \\
\text { dengan tidur siang }\end{array}$ & 0.6833 & 0.83839 & 0.503 & 0.932 & \\
\hline 21 & $\begin{array}{l}\text { Anda merasa tidak memiliki harapan / } \\
\text { putus asa }\end{array}$ & 0.1886 & 0.49643 & 0.599 & 0.931 & \\
\hline 22 & $\begin{array}{l}\text { Anda merasa tidak ada seorangpun yang } \\
\text { dapat membantu Anda untuk kondisi ini }\end{array}$ & 0.3452 & 0.68535 & 0.635 & 0.930 & \\
\hline 23 & $\begin{array}{l}\text { Anda mengalami perubahan berat badan } \\
\text { (tambah kurus / gemuk) }\end{array}$ & 0.8861 & 0.87496 & 0.408 & 0.933 & \\
\hline 24 & $\begin{array}{l}\text { Anda merasa tidak mampu mengatasi } \\
\text { stres yang muncul }\end{array}$ & 0.3701 & 0.59615 & 0.643 & 0.930 & \\
\hline 25 & $\begin{array}{l}\text { Anda sangat ingin / tetap keluar rumah, } \\
\text { walaupun kondisi di luar saat ini bahaya } \\
\text { / belum aman }\end{array}$ & 0.6370 & 0.78143 & 0.498 & 0.932 & \\
\hline 26 & Anda sering berpikir tidak mau bekerja & 0.4626 & 0.75085 & 0.583 & 0.930 & \\
\hline 27 & $\begin{array}{l}\text { Anda sering tidak dapat menyelesaikan } \\
\text { pekerjaan / tugas sesuai target / harapan }\end{array}$ & 0.5160 & 0.68707 & 0.637 & 0.930 & \\
\hline 28 & $\begin{array}{l}\text { Anda sering berpikir untuk } \\
\text { mengundurkan diri dari pekerjaan / } \\
\text { tugas Anda saat ini }\end{array}$ & 0.3452 & 0.66953 & 0.479 & 0.932 & \\
\hline
\end{tabular}

*Nilai median (minimum - maksimum) sebesar $0(0-3)$ poin 
Strain virus baru dari Coronavirus muncul dari kota Wuhan, Cina pada Desember 2019. Virus corona baru ini sangat menular dan hanya dalam beberapa bulan telah menjadi ancaman serius bagi kesehatan manusia di seluruh dunia 1. Penularan dari manusia ke manusia melalui tetesan atau kontak langsung memperkirakan masa inkubasi 6,4 hari dan jumlah reproduksi 2,24- 3,58 dari COVID19 mungkin bertanggung jawab atas penyebarannya yang cepat.2 WHO baru-baru ini mengumumkan COVID 19 sebagai penyakit keenam yang menyebabkan darurat kesehatan publik serta menjadi perhatian internasional. 3. COVID19 telah merenggut 288.239 nyawa di seluruh dunia hingga 12 Mei 2020. Bahkan negara-negara maju gagal mengendalikan peningkatan angka kematian akibat COVID 19.

COVID-19 tidak hanya menyebabkan permasalah fisik, melainkan menyebabkan pula beberapa reaksi psikologis. Beberapa referensi mengatakan bahwa beberapa gejala psikologis yang mungkin muncul ialah gejala psikosis, kecemasan, trauma, ide bunuh diri, serta gangguan panik selama wabah penyakit menular. Kecemasan adalah fasilitator penurunan respons imun terhadap infeksi dan semakin meningkatkan keparahan penyakit4

Pandemi COVID-19 dan isolasi seluruh negara cenderung meningkatkan timbulnya gangguan kecemasan akan penyakit baru dan menyebabkan eksaserbasi gejala pada kasus yang didiagnosis. Gejala flu sederhana seperti pada influenza mungkin akan meningkatkan kecemasan atau kekhawatiran terinfeksi COVID-19. Dikarenakan gejala COVID-19 dan penyakit seperti flu tumpang tindih seperti, batuk ringan dapat menciptakan rasa malapetaka atau kekhawatira yang sangat besar di antara masyarakat. Penggambaran yang berlebihan dari situasi saat ini di media telah menyebabkan kepanikan di masyarakat yang memicu gejala psikologis seperti Gangguan Kecemasan. (Cao et al., 2020; Huang \& Zhao, 2020). Penelitian Huang dan rekan-rekan mengungkapkan bahwa gangguan kecemasan muncul pada 35,1\% responden selama masa isolasi akibat COVID-19 (Huang \& Zhao, 2020) serta Penelitian Cao dan rekan yang mensurvei 7143 responden didapatkan hasil bahwa $0,9 \%$ responden mengalami gangguan kecemasan berat, $2,7 \%$ responden mengalami gangguan kecemasan sedang, dan $21,3 \%$ respondne mengalami gangguan kecemasan ringan. (Cao et al., 2020). Gejala psikiatri berupa kecemasan tertuang dalam beberapa bulir pertanyaan Kuesioner Cabin Fever dengan bulir pertanyaan nomor 2, 4, 10, 11, 14, 16, 17, 21, 22, dan 24. Perlu dilakukan telaah dan uji validitas-realibilitas lebih lanjut dengan menggunakan kuesioner lain yang sudah baku guna mengukur sejauh mana kesahihan dan kehandalan kuesioner ini untuk mendeteksi kecemasan

Penderita Gangguan Obsesif Kompulsif, terutama yang memiliki tipe obsesif golongan checking, hoarding and washing compulsion, berisiko lebih tinggi untuk mengalami gangguan psikologi di masa pandemic COVID-19. Pada saat keadaan normal atau tanpa tekanan saja, populasi kelompok ini sudah mengalami kekhawatiran yang cukup berlebihan, ditambah dengan dorongan kekhawatiran akan infeksi virus COVID-19 menimbulkan permasalahan seperti meningkatnya frekuensi obsesif dan kompulsi yang dialami. (Banerjee, 2020; Fineberg et al., 2020) Gangguan Obsesif Kompulsif memiliki beban kesehatan yang cukup mengkhawatirkan. Bahkan sebelum COVID-19 melanda dunia, ia memiliki prevalensi sebesar 2-3 persen. Gangguan kecemasan (gangguan panik, gangguan kecemasan umum, fobia, serangan panik) membentuk komorbiditas paling umum yaitu 70 persen dan gangguan depresi sekitar 30 persen (Cooper, 2017). Dari beberapa domain gejala obsessions of contamination dan compulsive hand washing adalah yang paling umum. Juga, telah terlihat bahwa meskipun domain ini merespon dengan baik terhadap farmakoterapi dan psikoterapi, ia cenderung mudah kambuh dalam kasus stres karena isyarat 
atau rangsangan eksternal atau lingkungan (Cordeiro et al., 2015) Gejala psikiatri berupa obsesif kompulsif tertuang dalam beberapa bulir pertanyaan Kuesioner Cabin Fever dengan bulir pertanyaan nomor 2, 6, 9, dan 17. Perlu dilakukan telaah dan uji validitas-realibilitas lebih lanjut dengan menggunakan kuesioner lain yang sudah baku guna mengukur sejauh mana kesahihan dan kehandalan kuesioner ini untuk mendeteksi obsesif kompulsif. Disisi lain, perlu juga dilakukan pembanding dengan menggunakan kriteria yang lebih baku seperti penggunaan kriteria yang ada pada DSM dan PPDGJ.

Pada pasien yang sudah terdiagnosa gangguan depresi berulang, keadaan isolasi dalam sebuah ruangan dapat menjadi stimulus stres utama yang mengancam rutinitas normal sehari-hari, ritme sosial dan dengan demikian meningkatkan tingkat stres, yang selanjutnya akan meningkatkan tingkat kortisol, yang mengakibatkan eksaserbasi dari gejala depresi. Ketidakmampuan untuk bekerja, berkurangnya keuangan dan dampak jangka panjang pada ekonomi akan berdampak pada penyakit depresi baru dan yang sudah ada sebelumnya. (Dong \& Bouey, 2020; Huang \& Zhao, 2020; Sønderskov et al., 2020) Pada orang dengan gangguan kejiwaan sebelumnya, semua masalah ini dapat muncul dengan tingkat keparahan baru dan dapat menyebabkan PTSD atau bahkan pikiran dan upaya bunuh diri. (Dong \& Bouey, 2020) Penelitian Huang dan rekan mengungkapkan 20,1\% responden dari 7236 sampel penelitian mengalami gangguan depresi dengan intensitas yang beragam. (Huang \& Zhao, 2020) Gejala psikiatri berupa depresi diuraikan dalam beberapa poin dalam kuesioner ini dengan bulir nomor 1, 3-6, 9, 10-16, 18, 21 28. Penelaahan lebih lanjut mengenai kesahihan dan kehandalan perlu dilakuka dengan membandingkan dengan kuesioner lain yang lebih baku dan penggunaan kriteria khusus seperti yang dianjurkan oleh PPDGJ dan DSM

Beberapa gangguan lain yang mungkin muncul akibat isolasi selama masa Pandemik COVID-19 adalah penyalahgunaan zat. Permasalahan ini muncul pada dua kelompok populasi yaitu kelompok yang belum pernah menyalahgunakan zat dan kelompok yang telah menyalahgunakan zat telarang. Pada kelompok yang belum pernah menyalahgunakan zat terlarang, substance abuse muncul sebagai akibat permasalahan depresi akibat COVID-19. (Chang et al., 2016) Untuk pasien gangguan penggunaan narkoba, periode ini bisa mematikan karena tidak tersedianya bahan atau obat-obatan dapat memicu severe withdrawal symptoms dan keadaan darurat medis seperti delirium atau kejang, yang dapat mengancam jiwa karena aksesibilitas yang tidak memadai. (Bonnet \& Preuss, 2017; Hindu, n.d.) Kurangnya akses akan medikasi dan layanan kesehatan juga memicu terjadi psychosis pada pasien-pasien dengan gangguan psikiatri mayor seperti Skizofrenia dan Gangguan Bipolar. (Ellenbroek, 2016; Hindu, n.d.; Young \& Fristad, 2016). Bulir pertanyaan untuk mendeteksi dini kejadian penyalahgunaan zat sebenarnya bersinggungan dengan bulir untuk mendeteksi kecemasan dan gejala depresi. Adapun yang secara khusus mendeteksi penyalahgunaan zat adalah bulir pertanyaan nomor $6,10,12$, 15, dan 16.

Gangguan tidur merupakan salah satu gangguan psikiatri yang dapat muncul selama masa Pandemik yang merupakan manifestasi gangguan psikiatri lainnya atau merupakan gangguan akibat berubahnya irama sirkadian. (Han et al., 2012; Morin et al., 2015) Ganggian tidur atau insomnia muncul pada masa Pandemik COVID-19 dengan angka yang cukup tinggi. Penelitian Huang dan rekan menyatakan bahwa 18,2\% dari 7236 responden terdiagnosa insomnia dengan intensitas yang beragam. (Huang \& Zhao, 2020) Penelitian Kokou-Kpolou dan kawan-kawan menyatakan 19,1\% dari 556 responden terdiagnosa insomnia berdasarkan kuesioner Insomnia Severity Index (ISI) selama masa Pandemik COVID-19. (Kokou-Kpolou et al., 2020). Kuesioner 
ini memfasilitasi beberapa kuesioner yang telah baku dalam memprediksi atau deteksi dini gangguan tidur akibat isolasi waktu yang cukup lama. Adapun bulir pertanyaan untuk memfasilitasi gejala gangguan tidur adalah bulir nomor 1, 3, 6, 10, 11, 15, dan 18-20.

Bunuh diri atau suicide merupakan sebuah permasalahan yang wajib diperhatikan selama masa COVID-19 (Gunnell et al., 2020; Mamun \& Griffiths, 2020). Bunuh diri dilaporkan merupakan penyebab utama kedua kematian non-coronavirus di India saat masa lockdown, menurut data yang dikumpulkan oleh jurnalis Rachel Chitra. Sebuah penelitian serupa oleh sekelompok peneliti menemukan bahwa 168 dari 326 kematian non Covid-19 hingga 9 Mei 2020 (51\%) adalah bunuh diri. Ada banyak kasus bunuh diri, yang disebabkan oleh ketakutan akan infeksi, kesepian, kurangnya kebebasan bergerak, dan putus alkohol selama masa lockdown. Karena efek withdrawal, tujuh orang meninggal akibat mengkonsumsi zat pencukur dan lotion pembersih yang dianggap sebagai alkohol. Beberapa laporan juga mengungkapkan kejadian bunuh diri muncul akibat kucilan atau rasa malu akibat stigma masyarakat yang melekat akibat infeksi COVID-19. (Hindu, n.d.). Menyakiti diri sendiri merupakan salah satu permasalahan psikiatri yang masuk dalam kategori berbahaya.Gejala ini timbul sebagai manifestasi gabungan dari gejala depresi mayor, kecemasan yang berlebihan, gangguan tidur kronis, dan penyalahgunaan zat.

Gejala psikiatri minor lainnya yang mungkin muncul sebagai akibat masa isolasi COVID-19 diungkapkan pada penelitian Jiao dan rekan. Gejala psikiatri yang dapat muncul berupa rasa tidak nyaman atau agitasi, mimpi buruk, mudah Lelah, penurunan nafsu makan, gangguan tidur, kekhawatiran akan masalah kesehatan, masalah obsesif akan berita terbaru, kekhawatiran, iritabilitas, dan gangguan perhatian dengan prevalensi dari 10 hingga 35\%. (Jiao et al., 2020)

Kuesioner Cabin Fever Phenomenon (CFP) Versi Indonesia diharapkan dapat menjadi acuan dalam deteksi dini munculnya gejala psikiatri pada populasi yang terkurung dalam waktu lama seperti penjara dan panti jompo.

\section{KESIMPULAN}

Cabin Fever Phenomenon (CFP) Versi Indonesia terbukti memiliki kesahihan yang baik serta kehandalan yang sangat baik untuk mendeteksi munculnya gejala psikiatri selama masa isolasi. Adapun gejala psikiatri yang mungkin timbul selama masa isolasi yang berkepanjangan adalah kecemasan, depresi, obsesif kompulsif, penyalahgunaan zat, gangguan tidur, bahkan hingga bunuh diri. Perlu dilakukan uji kesahihan lanjutan seperti uji kesahihan eksternal.

\section{Ucapan Terima Kasih (Acknowledgement)}

Ucapan terimakasih kami haturkan kepada berbagai pihak lintas sectoral yang telah berpartisipasi dalam penyusunan kuesioner ini melalui diskusi mendalam. 


\section{REFERENSI}

Banerjee, D. D. (2020). The other side of COVID-19: Impact on obsessive compulsive disorder (OCD) and hoarding. Psychiatry Research, 288, 112966. https://doi.org/10.1016/j.psychres.2020.112966

Bonnet, U., \& Preuss, U. (2017). The cannabis withdrawal syndrome: current insights. Substance Abuse and Rehabilitation, Volume 8, 9-37. https://doi.org/10.2147/SAR.S109576

Cao, W., Fang, Z., Hou, G., Han, M., Xu, X., Dong, J., \& Zheng, J. (2020). The psychological impact of the COVID-19 epidemic on college students in China. Psychiatry Research, 287, 112934. https://doi.org/10.1016/j.psychres.2020.112934

Chang, H., Huang, M.-C., \& Chen, L.-Y. (2016). Major Depressive Disorder Induced by Chronic Ketamine Abuse. The Primary Care Companion For CNS Disorders. https://doi.org/10.4088/PCC.15101881

Cooper, R. (2017). Diagnostic and statistical manual of mental disorders (DSM). In Knowledge Organization. https://doi.org/10.5771/0943-7444-2017-8-668

Cordeiro, T., Sharma, M., Thennarasu, K., \& Janardhan Reddy, Y. (2015). Symptom dimensions in obsessive-compulsive disorder and obsessive beliefs. Indian Journal of Psychological Medicine, 37(4), 403. https://doi.org/10.4103/0253-7176.168579

Dong, L., \& Bouey, J. (2020). Public Mental Health Crisis during COVID-19 Pandemic, China. Emerging Infectious Diseases, 26(7), 1616-1618. https://doi.org/10.3201/eid2607.200407

Ellenbroek, B. A. (2016). Schizophrenia. In The Curated Reference Collection in Neuroscience and Biobehavioral Psychology. https://doi.org/10.1016/B978-0-12-809324-5.00424-7

Fineberg, N. A., Van Ameringen, M., Drummond, L., Hollander, E., Stein, D. J., Geller, D., Walitza, S., Pallanti, S., Pellegrini, L., Zohar, J., Rodriguez, C. I., Menchon, J. M., Morgado, P., Mpavaenda, D., Fontenelle, L. F., Feusner, J. D., Grassi, G., Lochner, C., Veltman, D. J., ... Dell'Osso, B. (2020). How to manage obsessive-compulsive disorder (OCD) under COVID-19: A clinician's guide from the International College of Obsessive Compulsive Spectrum Disorders (ICOCS) and the Obsessive-Compulsive and Related Disorders Research Network (OCRN) of the Europ. Comprehensive Psychiatry, 100, 152174. https://doi.org/10.1016/j.comppsych.2020.152174

Guessoum, S. B., Lachal, J., Radjack, R., Carretier, E., Minassian, S., Benoit, L., \& Moro, M. R. (2020). Adolescent psychiatric disorders during the COVID-19 pandemic and lockdown. Psychiatry Research, 291, 113264. https://doi.org/10.1016/j.psychres.2020.113264

Gunnell, D., Appleby, L., Arensman, E., Hawton, K., John, A., Kapur, N., Khan, M., O’Connor, R. C., Pirkis, J., Appleby, L., Arensman, E., Caine, E. D., Chan, L. F., Chang, S.-S., Chen, Y.-Y., Christensen, H., Dandona, R., Eddleston, M., Erlangsen, A., ... Yip, P. S. (2020). Suicide risk and prevention during the COVID-19 pandemic. The Lancet Psychiatry, 7(6), 468-471. https://doi.org/10.1016/S2215-0366(20)30171-1

Han, K. S., Kim, L., \& Shim, I. (2012). Stress and Sleep Disorder. Experimental Neurobiology. https://doi.org/10.5607/en.2012.21.4.141

Hindu, B. (n.d.). Handbook of Mental Health Issues During COVID19 Pandemic.

Huang, Y., \& Zhao, N. (2020). Generalized anxiety disorder, depressive symptoms and sleep quality during COVID-19 outbreak in China: a web-based cross-sectional survey. Psychiatry Research, 288, 112954. https://doi.org/10.1016/j.psychres.2020.112954 
Jiao, W. Y., Wang, L. N., Liu, J., Fang, S. F., Jiao, F. Y., Pettoello-Mantovani, M., \& Somekh, E. (2020). Behavioral and Emotional Disorders in Children during the COVID-19 Epidemic. The Journal of Pediatrics, 221, 264-266.e1. https://doi.org/10.1016/j.jpeds.2020.03.013

Kokou-Kpolou, C. K., Megalakaki, O., Laimou, D., \& Kousouri, M. (2020). Insomnia during COVID-19 pandemic and lockdown: Prevalence, severity, and associated risk factors in $\begin{array}{lllll}\text { French population. Psychiatry } & \text { Research, }\end{array}$ https://doi.org/10.1016/j.psychres.2020.113128

Mamun, M. A., \& Griffiths, M. D. (2020). First COVID-19 suicide case in Bangladesh due to fear of COVID-19 and xenophobia: Possible suicide prevention strategies. Asian Journal of Psychiatry, 51, 102073. https://doi.org/10.1016/j.ajp.2020.102073

Morin, C. M., Drake, C. L., Harvey, A. G., Krystal, A. D., Manber, R., Riemann, D., \& Spiegelhalder, K. (2015). Insomnia disorder. Nature Reviews Disease Primers. https://doi.org/10.1038/nrdp.2015.26

Rosenblatt, P. C., Anderson, R. M., \& Johnson, P. A. (1984). The meaning of "cabin fever." Journal of Social Psychology. https://doi.org/10.1080/00224545.1984.9924512

Rothan, H. A., \& Byrareddy, S. N. (2020). The epidemiology and pathogenesis of coronavirus disease (COVID-19) outbreak. In Journal of Autoimmunity. https://doi.org/10.1016/j.jaut.2020.102433

Schulmeyer, M. C. C. (2020). COVID-19. In Revista Chilena de Anestesia. https://doi.org/10.25237/REVCHILANESTV49N03.01

Sohrabi, C., Alsafi, Z., O’Neill, N., Khan, M., Kerwan, A., Al-Jabir, A., Iosifidis, C., \& Agha, R. (2020). World Health Organization declares global emergency: A review of the 2019 novel coronavirus (COVID-19). In International Journal of Surgery. https://doi.org/10.1016/j.ijsu.2020.02.034

Sønderskov, K. M., Dinesen, P. T., Santini, Z. I., \& Østergaard, S. D. (2020). The depressive state of Denmark during the COVID-19 pandemic. Acta Neuropsychiatrica, 1-3. https://doi.org/10.1017/neu.2020.15

Tonks, A. (2008). Cabin fever. In BMJ. https://doi.org/10.1136/bmj.39511.444618.ad

Velavan, T. P., \& Meyer, C. G. (2020). The COVID-19 epidemic. In Tropical Medicine and International Health. https://doi.org/10.1111/tmi.13383

Young, A. S., \& Fristad, M. A. (2016). Bipolar Disorder. In Encyclopedia of Mental Health: Second Edition. https://doi.org/10.1016/B978-0-12-397045-9.00002-1 
